\title{
Puma Puma concolor density estimation in the Mediterranean Andes of Chile
}

\author{
Nicolás Guarda, Nicolás Gálvez, Jorge Leichthe \\ Christian OSORIO and Cristian BOnACIC
}

\begin{abstract}
Knowledge about the puma Puma concolor in the Mediterranean Andes of South America is scarce, with little information available about its distribution and ecology. The species has been hunted in the region for centuries and seems to be relegated to remote areas, where it still comes into conflict with rural communities. Camera-trap surveys have been used to estimate puma density across the species' distribution, and this is a relatively cost-effective approach to generate information about species abundance. We tested the performance of this method in the Andes of central Chile, where the rugged topography, unknown detection probability, and an expected low density make abundance estimation by other methods unreliable or expensive. Using a rotation of 17 camera-trap stations, for a total of 680 camera-days, we obtained 16 records of pumas and were able to identify four individuals in an effective sampling area of $628 \mathrm{~km}^{2}$ (1/2 mean maximum distance moved) or $1,518 \mathrm{~km}^{2}$ (mean maximum distance moved). Capturerecapture models estimated a minimum density of $0.3 \pm$ SE 0.07 to $0.75 \pm$ SE 0.17 adult pumas per $100 \mathrm{~km}^{2}$. This is the first estimate of the density of the puma in the Mediterranean Andes, and one of the lowest reported for the Neotropics. Although this low abundance does not necessarily imply a threat to the species, it suggests that the population is potentially vulnerable to threats such as illegal hunting. Our findings demonstrate that camera trapping is an effective technique in difficult field conditions and may be the most appropriate method to assess puma densities in this region.
\end{abstract}

Keywords Camera trap, Chile, density, mean maximum distance moved, Mediterranean Andes, Puma concolor

$\mathrm{P}$ uma Puma concolor populations throughout most of the Andes have received little research attention for decades, even though the mountain range is possibly a key corridor for the subspecies Puma concolor puma (Culver et al., 2000), comprising several thousand kilometres of wild

\footnotetext{
Nicolás Guarda (Corresponding author), Nicolás GálveZ*, Jorge Leichtle, Christian Osorio and Cristian Bonacic Fauna Australis Wildlife Laboratory, Department of Ecosystems and the Environment, Faculty of Agronomy and Forestry, Pontificia Universidad Católica de Chile, El Monasterio 932, Las Condes, Santiago, Chile. E-mail onguarda@uc.cl

*Also at: Department of Natural Sciences and Centre for Local Development, Pontificia Universidad Católica de Chile, Campus Villarrica, Chile

Received 15 May 2015. Revision requested 31 July 2015.

Accepted 4 November 2015. First published online 18 May 2016.
}

habitat in a north-south axis, with low human intervention. In the Mediterranean ecoregion of central Chile $\left(29-34^{\circ} \mathrm{S}\right)$, the high human density and intensive agriculture have rendered most of the area between the Andes foothills and the Pacific Ocean unsuitable for the species. The remaining natural habitat for the puma is in remote mountainous areas used as summer ranges for livestock (horses, cattle, sheep or goats), and managed by extensive grazing husbandry practices. In these areas retaliatory killing of pumas occurred for centuries prior to protection of the species in 1981, and may still occur, although the frequency is unknown. The puma's prey base has changed substantially since the 15th century, as the guanaco Lama guanicoe (a South American wild camelid) has disappeared from most of the country and been replaced by exotic lagomorphs (European rabbit Oryctolagus cuniculus and European hare Lepus europaeus), which are significantly smaller in size. Despite the potential threats to the puma (i.e. illegal hunting, reduced prey base) and its role as a top predator (Ripple \& Beschta, 2008; Ripple et al., 2014), little information is available about the species in this region. This not only hampers conservation efforts but also precludes evaluation of the species' conservation status in the region. Although the puma is categorized as Near Threatened by the Chilean authorities (MINSEGPRES, 2012), this assessment was based on little quantitative data; only two estimates of the density of the puma have been published in Chile, both carried out in Patagonia using radio and global positioning system (GPS) telemetry (Franklin et al., 1999; Elbroch \& Wittmer, 2012). This region differs markedly from the rest of the continent and cannot be considered representative of the other ecosystems of Chile.

The high cost of GPS telemetry and the poor accessibility of mountainous areas for radio-tracking preclude their general use for the assessment of puma populations. Camera traps may be used to overcome some of the complexities of estimating the abundance of large carnivores (Karanth \& Nichols, 1998). Data generated using camera traps have been used to estimate the density of the puma throughout its range (e.g. Kelly et al., 2008; Negrões et al., 2010; Paviolo et al., 2009), although there is still debate about some methodological issues, such as individual identification accuracy and ad hoc estimation of effective sampling surface (Foster \& Harmsen, 2012). However, it is unclear if this approach would facilitate abundance estimation in the Mediterranean Andes, where the rugged topography and an expected low puma density may render the technique 


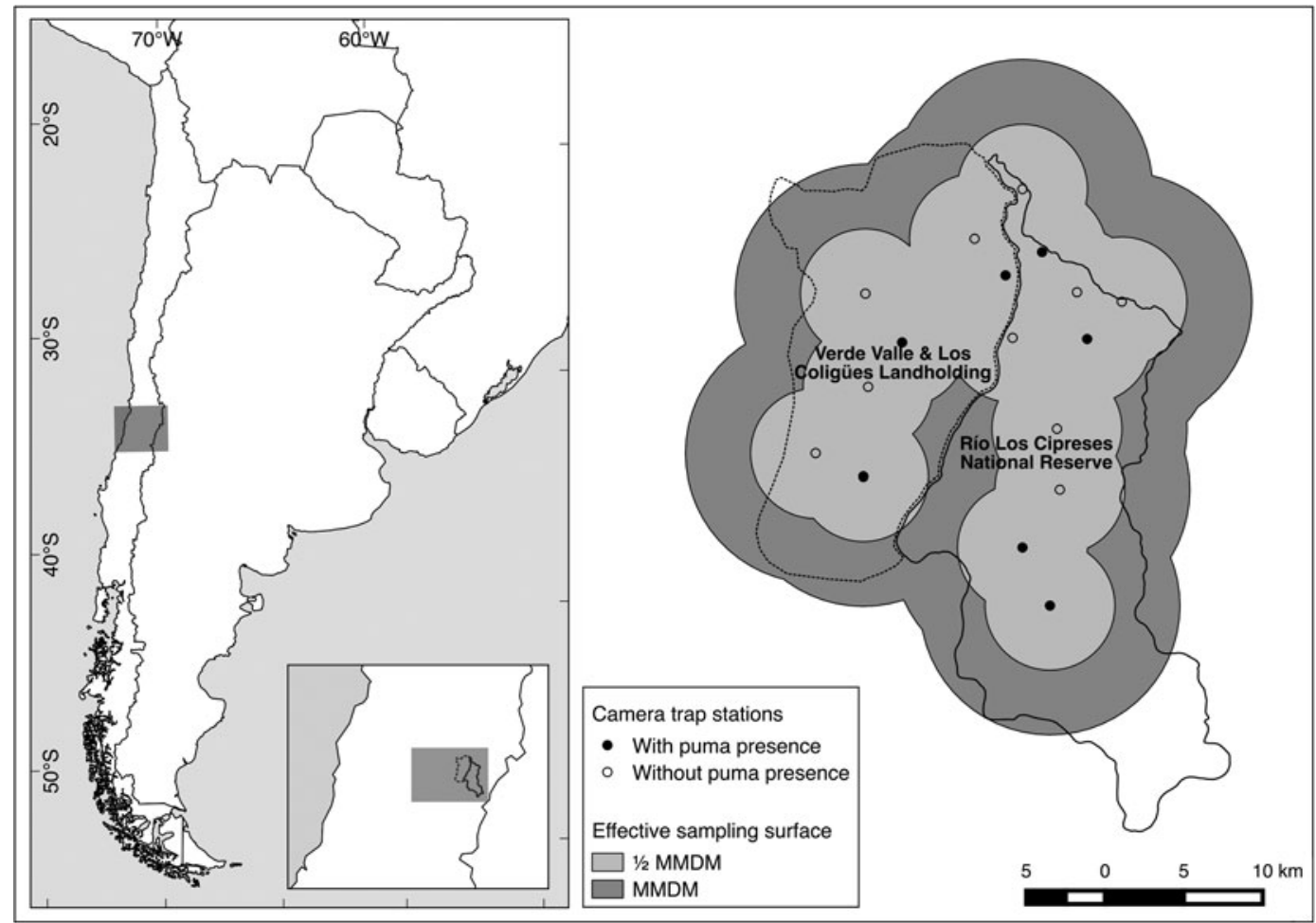

FIG. 1 Map of the study area in Chile (Río Los Cipreses National Reserve and adjacent landholdings) and the distribution of camera trap stations.

inappropriate. This study is the first attempt to estimate puma density in this region, where there is a need to facilitate assessment of the species' conservation status and to mitigate conflict with rural communities.

The study was carried out in Río Los Cipreses National Reserve and adjacent landholdings with extensive livestock husbandry practices (Verde Valle and Los Coligües landholdings) in the Mediterranean Andes (Fig. 1). The topography of the study area is characterized by basins of glacial origin surrounded by steep mountain chains, and the vegetation by an altitudinal gradient of dense sclerophyllous forests (900-1,300 m), a transitional thorny shrub (1,300-1,800 m), and Andean steppe in the highlands $(>1,800 \mathrm{~m})$.

We used 18 double camera-trap stations, baited with wild cat lure, to estimate puma density. Given the limited number of camera traps available we used a block design (e.g. Karanth \& Nichols, 1998; Soisalo \& Cavalcanti, 2006) to cover a significant area for the species (four times the mean territory size is recommended by Maffei \& Noss, 2008) while maintaining a spacing between stations that would not leave gaps in the coverage (i.e. that a puma using the area would not have zero probability of being detected; Foster \& Harmsen, 2012). We considered a maximum distance of $5 \mathrm{~km}$ between stations would be sufficient to achieve this goal, given a low expected puma density and a large territory size resulting from low availability of prey.
Potential camera trap sites were defined within a $300 \mathrm{~km}^{2}$ polygon (4.4 times the mean territory size reported for Patagonia by Franklin et al., 1999), spanning two adjoining basins. Following similar criteria to Jackson et al. (2006), cameras were placed along trails on topographical bottlenecks on ridgelines or valley bottoms, considering likely travel paths connecting distinct landscape units. Nine stations, each with two camera traps, were deployed within the protected area for 40 days and then moved to the livestock ranges for an identical period. One of the stations was stolen during the second rotation and no data could be retrieved, and therefore the analysis is based on 17 stations only.

Photographs of pumas were analysed independently by NG, NG and JL, who identified individuals based on stable and variable traits (Negrões et al., 2010), followed by a joint evaluation (Kelly et al., 2008). Each individual's capturerecapture history was built, dividing the sampling period into 16 5-day periods. Data were analysed using the Rcapture package (Baillargeon \& Rivest, 2014) in $R v$. 3.1.1 (R Development Core Team, 2015) and the model with the best relative fit was selected based on the Akaike Information Criterion. We treat both sampling periods as if they had been carried out simultaneously (Soisalo \& Cavalcanti, 2006), although we acknowledge the spatio-temporal biases such an approach might introduce (Foster \& Harmsen, 2012).

To estimate the effective sampling area we used the mean maximum distance moved, as well as half that value, to trace 
TABLE 1 Details of four individual pumas Puma concolor identified by camera trapping in the Mediterranean Andes of Chile (Fig. 1), with individual ID, camera trap station no., location, date, individual characteristics, maximum distance moved, and no. of captures.

\begin{tabular}{|c|c|c|c|c|c|c|}
\hline Individual & $\begin{array}{l}\text { Station } \\
\text { ID }\end{array}$ & Location & Date & Characteristics & $\begin{array}{l}\text { Maximum } \\
\text { distance } \\
\text { moved }\end{array}$ & $\begin{array}{l}\text { No. of } \\
\text { captures }\end{array}$ \\
\hline \multirow[t]{3}{*}{ Male 1} & 2 & Protected area & 12 Mar. 2012 & \multirow[t]{3}{*}{ Right ear mutilation; face scarring; male } & \multirow[t]{4}{*}{$16 \mathrm{~km}$} & \multirow[t]{3}{*}{3} \\
\hline & 2 & Protected area & 12 Feb. 2012 & & & \\
\hline & 6 & Protected area & 13 Mar. 2012 & & & \\
\hline Male 2 & 15 & Livestock ranges & 25 Apr. 2012 & $\begin{array}{l}\text { Marked tail kink to the left; no face scarring } \\
\text { or ear mutilation; male }\end{array}$ & & 1 \\
\hline \multirow[t]{2}{*}{ Female 1} & 2 & Protected area & 10 Feb. 2012 & Black tail tip; poor body condition; female & \multirow[t]{4}{*}{$4 \mathrm{~km}$} & \multirow[t]{2}{*}{2} \\
\hline & 1 & Protected area & 18 Mar. 2012 & & & \\
\hline \multirow[t]{2}{*}{ Female 2} & 11 & Livestock ranges & 20 Apr. 2012 & \multirow[t]{2}{*}{ Plain colour tail, no black tip; female } & & \multirow[t]{2}{*}{2} \\
\hline & 11 & Livestock ranges & 24 Apr. 2012 & & & \\
\hline
\end{tabular}

a buffer around all stations, using QGIS v. 2.2 (Quantum GIS Development Team, 2014). Although this approach has been criticized for being an ad hoc proxy of territory size and evidence for its convenience is inconsistent (Foster \& Harmsen, 2012), it was the only available information about puma movement in the study area. Also, its extensive use in literature facilitates comparison with similar studies.

Total sampling effort was 680 camera-days, as none of the cameras malfunctioned. During this period we obtained 16 records of pumas, in $47 \%$ of the stations $(n=8)$. Puma capture rate was 2.35 events per 100 camera-days. The mean capture rate inside the protected area $(2.8 \pm \mathrm{SE} 1.58$ events per 100 camera days) was substantially higher than in the livestock ranges (1.8 \pm SE 1.23 per 100 camera-days), and no individual was detected in both. Stations where puma presence was recorded previously had a higher visitation rate (6.88 events per 100 camera-days; $75 \%$ of 4 stations with puma presence) than those for which there were no previous records of puma presence (0.96 events per 100 camera-days; $38 \%$ of 13 stations with puma presence).

Half of the events $(n=8)$ resulted in photographs suitable for individual identification; many of the photographs taken at night were too blurred to allow clear observation of relevant features. From analysis of the photographs we were able to identify at least four individuals (two males, two females), three of them presenting clearly distinguishable traits (Table 1). Three of the identified individuals were captured on more than one occasion but only two were detected at more than one station, which resulted in a mean maximum distance moved of $10 \mathrm{~km}$ (Male 1, $16 \mathrm{~km}$; Female 1, $4 \mathrm{~km}$ ). The effective sampling area based on mean maximum distance moved was $1,518 \mathrm{~km}^{2}$, and based on half the mean maximum distance moved was $628 \mathrm{~km}^{2}$. Analysis of the capture-recapture data revealed that model $\mathrm{M}_{\mathrm{h} \text { Chao }}$ had the lowest Akaike Information Criterion value, estimating $4.7 \pm$ SE 1.1 pumas. Thus the puma density in the study area is estimated to be between $0.3 \pm$ SE 0.07 and $0.75 \pm$ SE 0.17 individuals per $100 \mathrm{~km}^{2}$.
This estimate of puma density is at the lower end of puma densities reported for the Neotropics, similar to those in the Atlantic Forest in Argentina (Kelly et al., 2008) but up to eight times lower than those in other areas (Table 2). This is consistent with low ecosystem productivity and reduced prey abundance in the study area. Although this low density does not necessarily imply conservation issues, it suggests that the population is vulnerable to threats such as illegal hunting (Chapron et al., 2008) and this could be a potential explanation for the difference in capture rate between the protected area and the livestock ranges. Conservation efforts should therefore focus on the study and alleviation of puma-human conflict, which could potentially be the main threat for this population. As such, the magnitude and characteristics of the conflict require further evaluation to assess its impact on the long-term survival of the species in this area.

Our estimate of density should be interpreted cautiously, however, and considered a minimum estimate. The low number of cameras available, the need to rotate them, and the use of only two captures to estimate the mean maximum distance moved may have compromised the accuracy and robustness of our results. Further evaluation is needed, with larger data sets for more robust estimation using spatially explicit capture-recapture models, an approach that would not be as sensitive to ad hoc proxies of territory size (Royle \& Gardner, 2011).

The capture rate we recorded was similar to other studies with similar densities, suggesting that the method performed well in this environment and that our camera location criteria (i.e. topographical bottlenecks on likely travel paths) were suitable. Given the success of this approach across a broad spectrum of environments and the high cost of alternatives involving individual capture, cameratrap studies may be the best method for determining puma density in this region. However, attention to detail to maximize capture probability is important. When working with species that are difficult to detect or about which 
TABLE 2 Estimates of puma density in the Neotropics, with study area, environment, method, no. of stations, no. of camera-trap days, capture success, effective sampling area based on $1 / 2$ MMDM, and data source.

\begin{tabular}{|c|c|c|c|c|c|c|c|c|}
\hline Study area & Environment & Method & $\begin{array}{l}\text { No. of } \\
\text { stations }\end{array}$ & $\begin{array}{l}\text { No. of camera- } \\
\text { trap days }\end{array}$ & $\begin{array}{l}\text { Capture } \\
\text { success }^{1}\end{array}$ & $\begin{array}{l}\text { Effective sampling } \\
\text { area based on } 1 / 2 \\
\operatorname{MMDM}^{2}\left(\mathrm{~km}^{2}\right)\end{array}$ & $\begin{array}{l}\text { Density estimate } \\
\text { (adults per } 100 \mathrm{~km}^{2} \text { ) }\end{array}$ & Source \\
\hline \multicolumn{9}{|l|}{ Argentina } \\
\hline Yabotí Biosphere Reserve & Atlantic forest & Camera trap & 42 & 1,871 & 2.41 & $1,199.33$ & $0.67 \pm 0.10^{3}$ & Kelly et al. (2008) \\
\hline Yabotí Biosphere Reserve & Atlantic forest & Camera trap & 42 & 1,871 & 2.4 & 1,082 & $0.74^{4}$ & Paviolo et al. (2009) \\
\hline Urugua-í & Atlantic forest & Camera trap & 34 & 1,496 & 1.07 & 228 & $2.19^{4}$ & Paviolo et al. (2009) \\
\hline Iguazú (2004) & Atlantic forest & Camera trap & 39 & 1,839 & 3.96 & 450 & $2.89^{4}$ & Paviolo et al. (2009) \\
\hline Iguazú (2006-2007) & Atlantic forest & Camera trap & 47 & $205 \mathrm{~T}$ & 3.89 & 750 & $2.4^{4}$ & Paviolo et al. (2009) \\
\hline \multicolumn{9}{|l|}{ Belize } \\
\hline $\begin{array}{l}\text { Chiquibul Forest Reserve \& } \\
\text { National Park }\end{array}$ & Tropical forest & Camera trap & 22 & 1,232 & 3 & 380.ee & $3.42 \pm 1.33^{3}$ & Kelly et al. (2008) \\
\hline Bolivia & & & & & & & & \\
\hline $\begin{array}{l}\text { Kaa-lya del Gran Chaco } \\
\text { National Park }\end{array}$ & Great Chaco & Camera trap & 17 & 1,601 & 2.84 & 96.33 & $6.8 \pm 1.05^{3}$ & Kelly et al. (2008) \\
\hline Brazil & & & & & & & & \\
\hline $\begin{array}{l}\text { Araguaia river basin } \\
\text { Chile }\end{array}$ & Tropical forest & Camera trap & 21 & 1,681 & 1.27 & 264.7 & $3.4 \pm 2.04^{3}$ & Negrões et al. (2010) \\
\hline $\begin{array}{l}\text { Torres del Paine National } \\
\text { Park }\end{array}$ & $\begin{array}{l}\text { Chilean } \\
\text { Patagonia }\end{array}$ & $\begin{array}{l}\text { Capture \& } \\
\text { telemetry }\end{array}$ & & & & & $2.5^{5}$ & Franklin et al. (1999) \\
\hline Southern portion of Aysen & Chilean & Capture \& & & & & & $1.35^{5}$ & Elbroch \& Wittmer (2012) \\
\hline District & Patagonia & GPS collar & & & & & & \\
\hline $\begin{array}{l}\text { Rio los Cipreses National } \\
\text { Reserve \& surroundings }\end{array}$ & $\begin{array}{l}\text { Mediterranean } \\
\text { Andes }\end{array}$ & Camera trap & 17 & 683 & 2.34 & 627.9 & $0.75 \pm 0.1^{3}$ & This study \\
\hline
\end{tabular}

${ }^{1}$ No. of captures per 100 trap-nights

${ }^{2}$ Mean maximum distance moved

${ }^{3}$ Mean \pm SE

${ }^{4}$ Maximum density considering a buffer of $1 / 2$ MMDM (no further details in original paper)

${ }^{5}$ Density based only on collared adults 
there is little local knowledge available, we advise examination of the entire polygon where cameras are going to be deployed. Although time consuming, this facilitates the identification of sites with the highest detection probability and reduces accessibility biases. In our study the best predictor of camera success was the prior detection of puma sign. Investing time in the identification of such sites is worthwhile, even if the substrate conditions and livestock traffic make it difficult to find sign, as was the case in our study.

\section{Acknowledgements}

This study was funded by Pacific Hydro Chile and Fondecyt 1120969. The O'Higgins regional office of CONAF (National Forestry Corporation) and the administration of the Río Cipreses Natural Reserve provided extensive logistical support. We thank Álvaro Aguilar, Joaquín López, Pablo Lobos, Juan Miguel Carrasco, Nelson Orellana, Ángel Lara and Raúl Silva. Nicolás Guarda, Christian Osorio and Nicolás Galvez are recipients of scholarships from Comisión Nacional de Investigación Científica y Tecnológica.

\section{References}

Baillargeon, S. \& Rivest, L.P. (2014) Rcapture: loglinear models for capture-recapture experiments. $R$ package v. 1.4-2. Https://cran. r-project.org/web/packages/Rcapture/Rcapture.pdf [accessed 18 November 2015].

Chapron, G., Miquelle, D.G., Lambert, A., Goodrich, J.M., Legendre, S. \& Clobert, J. (2008) The impact on tigers of poaching versus prey depletion. Journal of Applied Ecology, 45, $1667-1674$.

Culver, M., Johnson, W.E., Pecon-Slattery, J. \& O'Brien, S.J. (2000) Genomic ancestry of the American puma (Puma concolor). Journal of Heredity, 91, 186-197.

Elbroch, L.M. \& Wittmer, H.U. (2012) Puma spatial ecology in open habitats with aggregate prey. Mammalian Biology-Zeitschrift für Säugetierkunde, 77, 377-384.

Foster, R.J. \& Harmsen, B.J. (2012) A critique of density estimation from camera-trap data. The Journal of Wildlife Management, 76, 224-236.

Franklin, W.L., Johnson, W.E., Sarno, R.J. \& Iriarte, J.A. (1999) Ecology of the Patagonia puma Felis concolor patagonica in southern Chile. Biological Conservation, 90, 33-40.

Jackson, R.M., Roe, J.D., WAngChuk, R. \& Hunter, D.O. (2006) Estimating snow leopard population abundance using photography and capture-recapture techniques. Wildlife Society Bulletin, 34, $772-781$.
Karanth, K.U. \& Nichols, J.D. (1998) Estimation of tiger densities in India using photographic captures and recaptures. Ecology, 79, 2852-2862.

Kelly, M.J., Noss, A.J., Di Bitetti, M.S., Maffei, L., ArisPe, R.L., PAVIolo, A. et al. (2008) Estimating puma densities from camera trapping across three study sites: Bolivia, Argentina, and Belize. Journal of Mammalogy, 89, 408-418.

Maffei, L. \& Noss, A.J. (2008) How small is too small? Camera trap survey areas and density estimates for ocelots in the Bolivian Chaco. Biotropica, 40, 71-75.

MINSEGPRES (2012) Decreto Supremo 42/2012. Ministerio Secretaría General de la Presidencia, Government of Chile, Santiago, Chile.

Negrões, N., Sarmento, P., Cruz, J., Eira, C., Revilla, E., FonseCA, C. et al. (2010) Use of camera-trapping to estimate puma density and influencing factors in Central Brazil. The Journal of Wildife Management, 74, 1195-1203.

Paviolo, A., Di Blanco, Y.E., De Angelo, C.D. \& Di Bitetti, M.S. (2009) Protection affects the abundance and activity patterns of pumas in the Atlantic Forest. Journal of Mammalogy, 90, 926-934.

Quantum GIS Development Team (2014) Quantum GIS Geographic Information System. Open Source Geospatial Foundation Project. Http://qgis.osgeo.org.

R Development Core Team (2015) R: A Language and Environment for Statistical Computing. R Foundation for Statistical Computing, Vienna, Austria.

Ripple, W.J. \& Beschta, R.L. (2008) Trophic cascades involving cougar, mule deer, and black oaks in Yosemite National Park. Biological Conservation, 141, 1249-1256.

Ripple, W.J., Estes, J.A., Beschta, R.L., Wilmers, C.C., Ritchie, E. G., Hebblewhite, M. et al. (2014) Status and ecological effects of the world's largest carnivores. Science, 343, 1241484.

Royle, J.A. \& Gardner, B. (2011) Hierarchical spatial capturerecapture models for estimating density from trapping arrays. In Camera Traps in Animal Ecology: Methods and Analyses (eds A. F. O'Connell, J.D. Nichols \& K.U. Karanth), pp. 163-19o. Springer, Tokyo, Dordrecht, Heidelberg, London, New York.

Soisalo, M.K. \& Cavalcanti, S.M.C. (2006) Estimating the density of a jaguar population in the Brazilian Pantanal using camera-traps and capture-recapture sampling in combination with GPS radio-telemetry. Biological Conservation, 129, 487-496.

\section{Biographical sketches}

All authors are affiliated with the Fauna Australis Wildlife Laboratory of the Pontificia Universidad Católica de Chile, directed by CRISTI AN BonACIC. The main goal of this laboratory is to conduct applied research to address challenges in the conservation of threatened species. The authors specialize in various aspects of carnivore conservation, including species ecology and guild dynamics and the human and educational dimensions of wildlife conservation. The main emphasis of their research is to understand and resolve carnivore-livestock conflicts across the various ecosystems of Chile. 